IZA DP No. 6154

Religious Minorities and Provision of Public Goods: Evidence from Rural West Bengal

Pranab Kumar Das

Saibal Kar

Madhumanti Kayal

November 2011 


\title{
Religious Minorities and Provision of Public Goods: Evidence from Rural West Bengal
}

\author{
Pranab Kumar Das \\ Centre for Studies in Social Sciences, Calcutta \\ Saibal Kar \\ Centre for Studies in Social Sciences, Calcutta \\ and IZA \\ Madhumanti Kayal \\ Centre for Studies in Social Sciences, Calcutta
}

Discussion Paper No. 6154
November 2011

\author{
IZA \\ P.O. Box 7240 \\ 53072 Bonn \\ Germany \\ Phone: +49-228-3894-0 \\ Fax: +49-228-3894-180 \\ E-mail: iza@iza.org
}

\begin{abstract}
Any opinions expressed here are those of the author(s) and not those of IZA. Research published in this series may include views on policy, but the institute itself takes no institutional policy positions.

The Institute for the Study of Labor (IZA) in Bonn is a local and virtual international research center and a place of communication between science, politics and business. IZA is an independent nonprofit organization supported by Deutsche Post Foundation. The center is associated with the University of Bonn and offers a stimulating research environment through its international network, workshops and conferences, data service, project support, research visits and doctoral program. IZA engages in (i) original and internationally competitive research in all fields of labor economics, (ii) development of policy concepts, and (iii) dissemination of research results and concepts to the interested public.
\end{abstract}

IZA Discussion Papers often represent preliminary work and are circulated to encourage discussion. Citation of such a paper should account for its provisional character. A revised version may be available directly from the author. 
IZA Discussion Paper No. 6154

November 2011

\section{ABSTRACT}

\section{Religious Minorities and Provision of Public Goods: Evidence from Rural West Bengal ${ }^{*}$}

Religious and ethnic minorities across the world face partisan treatment with regard to provision of public goods, either as outcome of discriminatory practices or due to historical antecedents, such as the caste and religious divides in India. In several districts of West Bengal in India concentration of religious minorities, namely Muslims is higher than state and country-level averages. We measures access to public goods in rural West Bengal for different strata of minority concentration. Using Least Square, Generalized Linear Models and Blinder-Oaxaca decomposition, we find evidence of strong horizontal inequality against Muslims in terms of access to public goods. Blinder-Oaxaca decomposition shows that Muslims in larger concentrations face poorer access to infrastructure, health and transport facilities.

JEL Classification: H41, H51, J15, J71, I31

Keywords: religious minorities, public good, discrimination, welfare, West Bengal

Corresponding author:

Saibal Kar

Centre for Studies in Social Sciences, Calcutta

R-1, B. P. Township

Kolkata 700094

India

E-mail: saibal@cssscal.org

\footnotetext{
* The authors thank the Ministry of Minority Affairs, Government of India, Indian Council of Social Science Research, New Delhi, Ministry of Minority Affairs, Madrasah Education, Government of West Bengal and government officials in the districts of West Bengal and G. C. Manna, NSSO for facilitating the primary survey. We also thank Jyotsna Jalan for helpful discussion. The paper has benefited from presentation in the conference on 'Muslim Situation in India' at CSSSC. The usual disclaimer applies.
} 
IZA Discussion Paper No. 6154

November 2011

\section{NON-TECHNICAL SUMMARY}

Economic and social discrimination against religious and ethnic groups is common in many countries. However, direct evidence is often hard to come by. This paper uses a large sample survey of the minority concentrated districts in West Bengal (an eastern state in India with approximately the population size that of Germany) to document and formalize evidence on horizontal inequality in terms of access to public goods. The results corroborate the recent Justice Sachar Committee Report. The report focuses exclusively on the socioeconomic conditions of religious minorities in India. We collected primary household level data from 11 districts in rural West Bengal. We used this to investigate if religious minorities face horizontal inequality driven by provision of public good and whether such discrimination is quantifiable.

Thus, we focus on access to various types of public goods. We classify the minority population into three broad strata (Muslims form the largest minority group in West Bengal at $27 \%$ and almost twice the national average - the Indian sub-continent was partitioned on the basis of religion in 1947, India remained secular while East and West Pakistan proclaimed Islamic statehood).

We estimate the access to targeted and non-targeted public goods such as drinking water, distance to health facilities, distance and quality of educational facilities, transport facilities, condition of roads, etc. This is based on the level of minority concentration as well as other conventional explanatory factors like literacy level, access to information, participation in Panchayats (decentralized local self-governments), occupational types, etc. Using standard econometric models (viz. Ordinary Least Square and Generalized Linear Models) we reported a number of evidence with and without the minority group. In many cases, we observed that distance to block headquarter, literacy rate and the district factor for the worst quartile rank (according to district-level Human Development Indicator) are significant factors behind poor infrastructure and health facilities that minorities are exposed to.

As an extension, we report the Blinder-Oaxaca decomposition (that helps to decompose inter-group inequality into its contributing factors) for four major categories and computed both endowment effects and coefficients effects. At least for distance traveled to access health services and transport facilities, we report presence of extreme horizontal inequality in public provisions for places where minority concentration is rather high. For West Bengal it seems to counter the notion that disadvantaged minority groups can significantly influence supply of public goods through political representation. The distribution of public goods provisions in democracies like India depends critically on such representation.

Finally, these outcomes strongly support the main concern of Justice Sachar Committee Report. The paper provides direct evidence on the extent of horizontal inequality in access to public goods across religious communities. These results, although limited to a state in India, may be applicable to a broader context. In fact, continued discrimination or strategic negligence by the state has immense impact on socioeconomic exclusion of the people and may cause significant political disturbances. The fact that ethnic strife can result from public policies is a very recent subject of analysis with a multidisciplinary outreach. Some of these tensions have already surfaced in recent times and taken the shape of regional conflicts and moves towards cessation from the country or state. Further evidence on horizontal inequality in public provisions and religious/ethnic tensions should reshape public policies in future. 


\section{Introduction}

Religious minorities in India are defined on the basis of the National Commission of Minorities Act, 1992. This includes Muslims, Sikhs, Christians, Buddhists and Zoroastrians (Parsis). ${ }^{1}$ It is commonly held that among all religious groups the Muslims are by far the worst performers economically. Note that, unlike the large number of studies on caste categories and its impact on economic performances, comparison across religious groups and issues in reservation policies in India have been relatively few (Bardhan, Mookherjee and Parra Torrado, 2010 for West Bengal; Chin and Prakash, 2010 for India; Duflo, 2005; Pande, 2003, for India). This study is a contribution to this scant literature. We use an extensive baseline survey on socio-economic conditions of religious minorities in rural West Bengal, an eastern state in India. West Bengal is one of the most densely populated regions in the country and historically shared a high concentration of religious minorities.

India is historically fragmented in terms of religious, ethnic and caste groups. The prevalence of caste system offers additional distribution-related complexities rarely observed elsewhere. The prevailing socio-economic tension between caste groups, tribal groups (Kijima, 2006) and religious groups are often considered responsible for economic deprivation and inequality in India. Moreover, occasional conflicts, riots and general mistrust among religious groups make development-related issues quite contentious in the public domain. This provides a strong motivation to study the provision of and access to public goods in rural areas where religious and caste issues are still very important. We hypothesize that provision of public goods may be influenced by religious affiliations and regional concentration of such groups. In other words, the present paper studies whether public provisions vary significantly across religious groups in rural West Bengal.

\footnotetext{
${ }^{1}$ As per 2001 Census of India the percentages of different minority religious groups in total population Muslims are the largest (13.43\%) and in West Bengal they are in fact higher than national average (25.25\%).
} 
Interestingly, the provision of public goods is often used as a political instrument by the centralized or provincial or local level self governments (Sharif, 2011 for Sri Lanka comparing Sinhalese and Tamils; Sengupta, 2010 for role of political parties towards provision of public goods; Joanis, 2010, case of an electoral district in Quebec; Moser, 2008 for Madagascar; Banerjee and Somanathan, 2007 for rural India; Luo, Zhang, Huang and Rozelle, 2007 for rural China; Besley, Pande, Rahman and Rao, 2004 for South India, Crost and Kambhampati, 2010, for North India testing the role of local democracy in provision of school infrastructure, etc.). Empirically, various country studies substantiate this notion that the distribution of public goods tend to vary significantly across ethnic communities (for example, Banerjee, Iyer and Somanathan, 2005 for rural India; Miguel and Gugerty, 2005 for western Kenya; Brasington, 2003 for school districts and racial divide in the US; Alesina, Baqir and Easterly, 1999, for US cities, metropolitan areas and urban counties, etc.). However, none of these studies explicitly discuss provision of public goods across communities when religious affiliation is the main explanatory factor.

The disadvantage facing certain ethnic and religious groups may be seen as an outcome of political reservations in favor of others. Pande (2003) shows that political reservations lead to higher transfers to the groups that benefit from reservations, but there is typically no evidence in favor of a complete policy commitment. However, Duflo (2005) argues that if the preferences of the potential beneficiaries of reservations do not differ from rest of the population, then reservation does not offer a premium. On the point of preferences, Besley et al. (2004), defines publicly provided private goods as low spillover goods and include individual or household level cash transfers, ration cards, water connections, etc. These individualized services depend strongly on the nature of representation in the local governments as also the identity of the leader. The poorer sections 
will also have high preferences for the non-targeted public good (roads, schools, irrigation canals, railway stations, bridges, etc.) in their hamlets.

We evaluate the conditions of religious minorities in eleven districts of West Bengal in terms of access to public goods. For India in general, the Sachar Committee Report (2006) is the first ever report that systematically analyzes the conditions of religious minorities. The committee was set up for analyzing available data on the spatial concentration, occupational patterns, assets, general socio-economic conditions, employment share in public and private sector, access to education and health services, infrastructure and credit, etc. for religious minorities all over India. It reported extremely poor conditions facing religious minorities (specifically, Muslims). ${ }^{2}$ Even within the larger disadvantaged communities across religious groups, affirmative actions in education and jobs for Hindu lower caste and tribal population (Scheduled Castes and Scheduled Tribes, respectively) has pushed the Muslims at a relatively disadvantaged position.

The caste classification in India, which exists mainly among followers of Hindu religion, (but, also present among Muslims, Christians, Sikhs, Buddhists, etc.; Sachar Committee, 2006, p.6-7, Table 1.1 and 1.2) functions as a prejudice against certain groups. Lower caste population faces statistical discrimination by providers of public goods and suffers from lack of incentives for improvement (Arrow, 1972; Akerlof, 1976). Thus, castebased social relation creates a low-level equilibrium trap culminating into self-fulfilling prophecy. ${ }^{3}$ According to Sachar Committee (2006), "Caste, religion and regional/linguistic differentials in economic, social and political spheres in India have a historical basis and are deeply influenced by the extant socio-economic relationships, some of which have persisted

\footnotetext{
${ }^{2}$ Economic and social integration of Muslims has many implications as discussed in the literature. See for example Bisin et al (2008) for Muslims in UK. The Sachar Committee Report (2006, p. 11) observes how this particular community imagine themselves and is imagined by other socio-religious communities in India: "In general, Muslims complained that they are constantly looked upon with a great degree of suspicion not only by certain sections of society but also by public institutions and governance structures".

${ }^{3}$ Discussion of taste-based prejudice or discrimination (Becker, 1969; Welch, 1967) ignores historical perspective on which stability of institutions such as caste system or religious groups depend.
} 
for centuries. The Indian socio-economic fabric is more complex than ordinarily believed because of various unique layers and segments, into which Indian society is divided and subdivided." (p. 4).

The religious divide between Hindus and other much smaller religious groups is equally complex for the post-partition secular India and deeply rooted in its history (see Morris and Adelman, 1980 for the relationship between religious factors and economic development). This paper does not have the scope to discuss how the transition over a couple of centuries has left the majority of Muslims in India in considerable economic disadvantage vis-à-vis other religious groups. ${ }^{4}$ Besides, the results are obtained from a survey of eleven districts in only one state. Many districts in West Bengal have concentration of Muslims over $20 \%$ of the total population and this is higher than the national average. Apart from West Bengal this is also true for many districts in Bihar, Uttar Pradesh, Maharashtra, Andhra Pradesh, Kerala, Sikkim, the Andaman and Nicobar Islands, etc. with respect to Muslims, Christians, Sikhs or Buddhists. ${ }^{5}$ For West Bengal we utilize a recent household survey of minority concentrated districts commissioned by the Ministry of Minority Affairs, Government of India. The extensive survey has yielded several interesting socio-economic features which we discuss in section 3 .

Finally, the term 'religious minority' is a multi-layered construction. Any one-to-one correlation between a particular religion and level of development may fail to do justice to the complex realities. It touches politically and socially sensitive issues in religious discrimination and deprivation. ${ }^{6}$ As one of the related reports points out: "it is not the absence of physical amenities (only) that are preventing minorities from coming forward, it is

\footnotetext{
${ }^{4}$ Although partition in 1947 is a historical event, most discussions on current religious context in India finds its influence ramified along economic and political issues. Ahmed (2005, p. 1) comments that the politicization of religion in post-secular post-globalization India has transformed Indians into 'hauntological' beings.

${ }^{5}$ In fact Gujarat is an exception in the list or though it has very high Muslim concentration in many coastal districts, they are better performers when compared to national average.

${ }^{6}$ During the course of our survey words such as 'discrimination' and 'deprivation' were carefully articulated to the respondents.
} 
also the contextual background." ${ }^{77}$ While the Sachar Committee Report agrees that widespread perception of discrimination among the Muslim community needs to be addressed, it also admits that there are hardly any empirical studies that establish discrimination. Section 2 discusses data and methodology. Section 3 offers the results and section 4 concludes. Tables and methodologies are relegated to the appendix.

\section{Data and Methodology}

In the absence of appropriate data on religion specific socio-economic parameters in India it is a vexing task to continuously, even periodically, assess the extent and intensity of development deficits facing minority communities in general and Muslims in particular. ${ }^{8}$ We collected primary household level data for 11 districts in rural West Bengal during 2007-08. The main hypothesis is the following. Is the minority concentration in the rural areas an important determinant of the provision of public goods and social infrastructure? In this paper, public goods and infrastructure include, 'distance travelled to fetch drinking water', 'access to health facilities provided by the government', 'nearest bus stop', 'nearest railway station', 'nearest post office', 'number of teachers in schools', 'paved roads in the villages', 'electrification of houses', etc. Needless to mention, availability of infrastructure and public goods are well known for their influence on economic growth and development in any country.

The districts within West Bengal are selected on the basis of concentration of minority population, religion-specific socio-economic indicators and an indicator constructed from the various types of basic amenities available to the population. The four religion-

\footnotetext{
${ }^{7}$ See, Expert Committee Meeting on Baseline Survey of Minority Concentration Districts, Indian Council for Social Science Research, p. 4.

${ }^{8}$ Sachar Committee based their observations on Census of India 2001 and argued that huge deficits exist. Due to unavailability of data, the Ministry of Minority Affairs, Government of India commissioned a baseline survey in ninety districts across the country in 2007-08 of which eleven are in West Bengal. The survey was conducted in the rural areas only. This baseline survey was commissioned under the aegis of the Indian Council of Social Science Research.
} 
specific socio-economic indicators are: (i) overall literacy rate, (ii) female literacy rate, (iii) work participation rate, and (iv) female work participation rate. On the other hand, the four basic amenities are: (i) percentage of households with pucca (concrete) walls, (ii) percentage of households with safe drinking water, (iii) percentage of households with electricity and (iv) percentage of households with $\mathrm{W} / \mathrm{C}$ toilets.

We restrict our analysis to those districts in West Bengal (henceforth, WB) in which (a) the minority (Muslim) population is more than $20 \%$, and (b) the average of the religionspecific socio-economic indicators, and/ or (c) the average of the basic amenities indicators, are both lower than the respective national averages. The districts chosen have Muslim population well above the all-India average. They also report poor performance in terms of either religion specific socio-economic indicators and/ or basic amenities indicators. Both of these can be treated as indicators of backwardness. The districts selected for the study include Uttar Dinajpur, Dakshin Dinajpur, Malda, Murshidabad, Birbhum, Nadia, South 24 Parganas, Bardhaman, Coochbehar, Haora and North 24 Parganas. ${ }^{9}$ The first nine districts have lower than national socio-economic averages. For Haora and North 24 Parganas the 'basic amenities' indicators are lower than the national average. Table 1 provides some of the important indicators used for these districts. So far the Muslim minority population is concerned, some of the districts such as Bardhaman, Haora or North 24 Parganas perform quite well in terms of the state HDI rank but fall short of national averages for religion specific or basic amenities indicators. This highlights the fact that the disparity between nonMuslim population and Muslim population is worse in these districts.

\footnotetext{
${ }^{9}$ Table 6 in Appendix 2 shows that the share of religious minorities (predominantly Muslims) has increased unambiguously over the last three decades. This may have been caused by the natural rate of population growth in India and follow the trend among Muslims. It may also have been caused by legal/illegal immigration from Bangladesh. However, the population growth is marginal for most districts and it could not have lowered per capita availability of public goods to the very low level as one observes currently. It may certainly have worsened an already poor resource base.
} 


\section{Methodology}

We adopted a stratified multi-stage sampling design in which households are the targeted sampling units chosen from rural areas only. The first stage units (FSU) were the 2001 Census villages constituting the primary sampling units. In the first stage, the development blocks (comprising of a number of census villages) were classified into three strata on the basis of the percentage of Muslim population. The first stratum constitutes the top $20 \%$ blocks, second comprises of the middle $50 \%$ and the third represents the bottom $30 \%$. Ideally, the strata should have been constructed with census villages. However, religion-specific population data at the village level is 'classified' and therefore not available. For the next step, in case of districts with population in excess of 0.5 million a total of 30 villages were chosen and distributed in the three strata. The 30 villages distributed in the three stratums are chosen by the method of probability proportional to size. Subsequently, a total of 30 households were chosen from each village via random sampling with replacement. The households selected by standard listing method were proportionate to religious groups in the total population of the village. For large FSUs one intermediate stage of sampling had been the selection of hamlet groups. If village population is in excess of 1200 individuals, the entire village population is distributed into hamlet groups with each hamlet group covering population of 600 . The hamlet group with highest concentration of minority population is chosen with probability one and one more is chosen from the remaining hamlet groups randomly. This approach directly follows the sampling methodology adopted by the National Sample Survey of India ${ }^{10}$. A typical hamlet group consists of 600 individuals. In brief, therefore, we had 30 villages in each district if district population exceeded 0.5 million (which is generally the case in West Bengal) and 30 households from each village. On average, this amounts to 4500 individuals surveyed in each district for eleven districts.

\footnotetext{
${ }^{10}$ See National Sample Survey Organisation $(2001,2010)$ for general discussions on concepts and definitions.
} 
Table 1: Minority population and socio-economic scenario - District-wise

\begin{tabular}{|c|c|c|c|c|c|c|}
\hline District & $\begin{array}{l}\text { Muslim } \\
\text { Populatio } \\
\mathrm{n}(\%)\end{array}$ & $\begin{array}{l}\text { Populat } \\
\text { ion } \\
\text { Density }\end{array}$ & $\begin{array}{l}\text { Literacy } \\
\text { Male } \\
\text { (Female) } \\
(\%)\end{array}$ & $\begin{array}{l}\text { Sate } \\
\text { HDI } \\
\text { Rank }\end{array}$ & $\begin{array}{l}\text { Religion } \\
\text { Specific } \\
\text { Index of } \\
\text { Basic } \\
\text { amenities }\end{array}$ & $\begin{array}{l}\text { Religion } \\
\text { Specific } \\
\text { Index of } \\
\text { Socio eco. } \\
\text { indicators }\end{array}$ \\
\hline Coochbehar & 23.34 & 732 & $\begin{array}{c}66.3 \\
(56.1)\end{array}$ & 11 & 10.49 & 40.2 \\
\hline U. Dinajpur & 47.36 & 778 & $\begin{array}{c}47.89 \\
(37.51)\end{array}$ & 13 & 9.2 & 29.7 \\
\hline D. Dinajpur & 24.02 & 677 & $\begin{array}{c}63.59 \\
(55.12)\end{array}$ & 13 & 11.6 & 44.9 \\
\hline Malda & 49.72 & 881 & $\begin{array}{c}50.28 \\
(41.25) \\
\end{array}$ & 17 & 16.2 & 38.2 \\
\hline Murshidabad & 63.67 & 1101 & $\begin{array}{c}54.3 \\
(47.6) \\
\end{array}$ & & 17.8 & 35.4 \\
\hline Nadia & 25.4 & 1172.3 & $\begin{array}{c}66.14 \\
(59.58) \\
\end{array}$ & 9 & 24 & 35.3 \\
\hline North 24 Pgs. & 24.22 & 2182 & $\begin{array}{c}78.06 \\
(71.72) \\
\end{array}$ & 3 & 47.2 & 40.9 \\
\hline South 24 Pgs. & 33.24 & 694 & $\begin{array}{l}69.45 \\
(41.1)\end{array}$ & 8 & 21.2 & 36.6 \\
\hline Haora & 24.2 & 2912.8 & $\begin{array}{c}83.2 \\
(70.1)\end{array}$ & 2 & 47.4 & 41.6 \\
\hline Bardhaman & 20.36 & 982 & $\begin{array}{l}70.17 \\
(60.9)\end{array}$ & 5 & 35.52 & 43.2 \\
\hline Birbhum & 35.08 & 664 & $\begin{array}{c}61.48 \\
(51.55)\end{array}$ & 14 & 16.9 & 38.7 \\
\hline West Bengal & 25.25 & 903 & $\begin{array}{c}77.0 \\
(59.61)\end{array}$ & - & - & - \\
\hline All India & 13.43 & 325 & $\begin{array}{c}75.3 \\
(53.7) \\
\end{array}$ & - & 41.7 & 45.8 \\
\hline
\end{tabular}

Source: Census, 2001; State Human Development Report, 2004 


\section{Survey Questions}

For the survey, two types of questionnaires - a household questionnaire and a village schedule were used. The household questionnaire was used for identifying socio-economic factors influencing development, and for reporting individual as well as collective experiences of people living in these areas. The village schedule was used for collecting village-level data on infrastructure, general access to basic amenities including health facilities, education, land holdings and irrigation, etc. ${ }^{11}$

Provision of public good refers to includes following variables of critical import: (i) percentage of households using public source of drinking water, (ii) percentage of paved roads in the village, (iii) average distance travelled for accessing public health facility, (iv) distance to nearest bus stop, (v) distance to nearest railway station and (vi) an index of educational infrastructure for the village (or nearest) primary school. In addition, we considered the following two variables: (vii) percentage of houses electrified and (viii) percentage of households that do not avail of institutional delivery (child birth). Strictly speaking, (vii) and (viii) do not represent public provision of social infrastructure. While (vii) has characteristics of a private good, for rural areas in India the overhead cost is often very high and consequently, even richer sections find electricity connections prohibitively expensive. It becomes the responsibility of public sector companies to offer connections at subsidized rates. ${ }^{12}$ Next, percentage of households who do not avail of institutional delivery is actually an outcome variable. However, as a measure of the availability of publicly provided health facility including trained doctors, nurses and necessary equipments, it carries substantial importance. In particular, the distance travelled for availing of health facility,

\footnotetext{
${ }^{11}$ These are usually available from various government offices, like the office of the District Magistrate, the Block Development Officer, the Agricultural Department, the office of the Panchayat Pradhan (head of the local level self government), ICDS (Integrated Child Development Service) centres etc.

${ }^{12}$ However, state and federal governments in India offers certain schemes for provision of electricity to rural areas, which have public good characteristics to the supply of electricity.
} 
including childbirth is an important indicator of development at the village level. ${ }^{13}$

The results are based on village level data. The variables are averages for households surveyed in each village and include percentage of households using public source of drinking water, etc. For some of the other variables, such as, distance to the nearest railway station, we have used the village schedule data. For assessing public provision of educational infrastructure we constructed an index comprising of teacher-student ratio, type of school building, number of classrooms in the school, drinking water facility, toilet facility and percentage of students who received free books. For example, if the school building is pucca (with concrete roof) it is given a value of 3 , if it is semi pucca (concrete and clay constructions) the value is 2,1 if it is kutcha (only clay construction and no concrete) and 0 if the school has no building. Similarly, drinking water facility and toilet facility are given value 1 each, if available, and 0 if otherwise.

\section{Econometric Methodology and Results}

This section empirically investigates if the percentage of Muslim population at the village level is an important explanatory variable for provision of public goods and for the outcome variables. We regressed each of these public goods/ social infrastructure on the percentage of Muslim population in the village adequately controlled for other variables. Our econometric exercise essentially aims to explain whether provision of public goods listed above is biased against concentration of Muslim population in villages. To this end, we control for average land holding at the household level, distance of the block head-quarter from the village, distance of the nearest town from the village, percentage of male (landless) agricultural labourer in the village. Further, we consider literacy rate at the village level, percentage of households who read newspapers, percentage of households which actively

\footnotetext{
${ }^{13}$ Everywhere the village health centres are severely limited in terms of instruments and facilities and therefore offers little to the villagers. Unavailability of doctors, nurses and medicines forces patients to travel to far off towns on a regular basis (see for example Kar, 2011).
} 
participate in Gram Panchayat meetings and the average annual expenditure of households. These are directly computed from the household survey. Data on educational infrastructure, distance of village from the block head quarter and the nearest town are obtained from village survey data.

So, for each type of public good we estimated the following regression equation.

$$
y_{i}=\alpha+\gamma M_{i}+\beta \widetilde{X}_{i}+\theta D_{i}+u_{i}
$$

where $M_{i}=$ percentage of Muslim population in village $i, \widetilde{X}_{i}=$ vector of control variables for village $i, D_{i}=$ dummy if the district belongs to the lowest quartile in HDI rank, and $u_{i}=$ disturbance term.

The set of independent variables are: distance travelled for accessing public health facilities (in Km.) [computed as average distance travelled for accessing government hospital/ dispensary/clinic and primary health centres from the village], distance of bus stop (in $\mathrm{Km}$.), distance of railway station (in $\mathrm{Km}$.), average years of highest education [computed as average over households in each village based on the highest level of education for male and female members at the household level], proportion of households not accessing government facility for child birth (or, non-institutional delivery), proportion of paved roads, proportion of households electrified and proportion of households who have access to publicly provided drinking water.

On the other hand, the set of explanatory variables are (i) percentage of minority (Muslim) population in the village, (ii) average land holding (in bigha $=1 / 3$ acre), (iii) distance of block head quarter (in $\mathrm{Km}$.) ${ }^{14}$, (iv) nearest town (in $\mathrm{Km}$.), (v) reading newspaper, (vi) political participation [i.e., the percentage of households participating in Gram Panchayat meetings], (vii) agricultural labour (male), (viii) dummy if the district (to which the village belongs) belongs to the lowest quartile of HDI ranks for West Bengal as of 2004,

\footnotetext{
${ }^{14}$ Block is an administrative boundary below the district level.
} 
and finally, (ix) dummy if the village average household expenditure lies in the group of bottom $20 \%$ of villages in the state. As we have already mentioned, we are interested in observing how far the provision of various public goods is explained by village level concentration of Muslim population. Percentage of Muslim population is our main regressor while the variables listed from (ii) through (ix) are control variables.

We also estimated the same econometric model by using dummy for different strata of Muslim population. The strata with top $20 \%$, middle $50 \%$ and bottom $30 \%$ minority population in each district are arranged in descending order and categorized as S1, S2 and S3 respectively. The villages fall into these three categories. Thus, any two dummies can be used simultaneously along with the intercept term. The strata dummies are defined below.

$$
\begin{aligned}
& \begin{aligned}
S_{1 i} & =1 \text { if village } i \text { belongs to top } 20 \% \text { stratum } \\
& =0 \text { otherwise. } \\
S_{2 i} & =1 \text { if village } i \text { belongs to middle } 50 \% \text { stratum } \\
& =0 \text { otherwise. }
\end{aligned} \\
& \begin{aligned}
S_{3 i} & =1 \text { if village } i \text { belongs to bottom } 30 \% \text { stratum } \\
& =0 \text { otherwise. }
\end{aligned} \\
& \text { and } \widetilde{S}_{\mathrm{i}}=\left[\begin{array}{c}
S_{h i} \\
S_{k i}
\end{array}\right], h, k=1,2,3 \text { and } h \neq k
\end{aligned}
$$

Therefore, the reformulated regression equation is given by

$$
y_{i}=\alpha+\phi \widetilde{S}_{i}+\beta \widetilde{X}_{i}+\theta D_{i}+u_{i}
$$

where, $\phi=$ vector of parameters for strata dummies.

The econometric specifications in (1) and (2) are reduced forms of a choice problem of the government for allocating public goods across villages with 'religious concentration' as one of the determinants. Deliberate discrimination on the part of the state would mean that areas with minority concentration are neglected. It could also imply that resource allocation through representation in a democracy like India may be less functional than usually 
contemplated. Resource allocations may be subject not only to inter-regional tug-of-war, but also the overall economic condition of the state and its fiscal and political relations with the federal government. If one or more of these conditions go against minority groups, concentration of minority population is expected to have a negative impact on the provision of public goods. More importantly, the argument of reverse causality i.e. poor provision of public good influencing minority concentration is not tenable on the ground of individual rationality. If provision of public goods is poor in some villages then there is no reason why people, minority or majority, would choose to settle there unless there is a sudden influx due to purely exogenous reasons like political or religious persecution elsewhere. Table 6 does not indicate that there have been remarkable changes in the trends. So, the question of reverse causality is firmly ruled out. Finally, the basic difference between the econometric specifications (1) and (2) is the following. For relation (1) the relation is linear with Muslim concentration and for (2) the intercept shifts with the dummy (if, statistically significant). Average land holding represents average asset level of the village households. In addition, we consider average annual household expenditure used as a proxy for average annual income. To measure the extent of intra-village inequality, we use landless agricultural labour as percentage of the village population. It is often argued that villages proximate to block headquarter and towns receive better public facilities, perhaps by persistent lobbying for public goods. Hence, we consider distance to block headquarter and distance from the nearest town (in kilometres) as important explanatory factors. The percentage of households with at least one member regularly reading newspapers is also used as a control in the regression analysis to capture the level of literacy. It also reflects the awareness of the households regarding benefits of accessing health facilities, safe drinking water, government schemes currently operational, etc. ${ }^{15}$ Regarding provision of public goods and social

\footnotetext{
${ }^{15}$ Literacy itself is not a very good indicator because it is defined as ability to write one's name correctly.
} 
infrastructure the role of Gram Panchayat is generally believed to have a positive impact. This can be measured in many ways. We worked with household participation in Gram Panchayat meetings as a measure of the emphasis on village level decentralization.

Since the data captures a cross-section of villages, one should expect a lot of heterogeneity. However, as we considered dependent as well as explanatory variables either as percentages or averages across households, the level effect is neutralized. Hence, we regress the first set of equations by Ordinary Least Squares (OLS). It is followed by estimation using the Generalized Linear Model (GLM) where the dependent variables are in proportions. Moreover, both the Breusch-Pagan test and the White test confirm presence of heteroscedasticity. Thus, we re-estimated the model for the robust standard errors of coefficients. For the entire set of equations where $y_{i}$ is regressed on $\tilde{X}_{i}$ heteroscedasticityrobust estimator for $V\left(\widehat{\beta}_{j}\right)$ is given by: $V\left(\widehat{\beta}_{j}\right)=\frac{\sum_{i} \widehat{r}_{i j}^{2} \widehat{u}_{i}^{2}}{S S R_{j}^{2}}$, where $\widehat{\beta}_{j}=$ estimated coefficient for $j^{\text {th }}$ regressor, $\hat{u}_{i}=$ estimated residual from OLS, $\widehat{r}_{i j}=i^{\text {th }}$ residual from regressing $x_{j}$ on other $x^{\prime} s$ and $S S R_{j}=$ sum of squared residuals from this regression. Regression equations include either percentage of minority population or the minority population strata at the district level.

Additionally, for the public good/ social infrastructures that are measured in proportion, we estimated the corresponding model by GLM with logit link. Let us briefly justify adoption of this method. If a regressand is reported in percentage and the variable is restricted to [0 1] interval, then GLM with logit link and the binomial family is a natural selection. It is because of the fact that the functional forms automatically impute the endogenous variable in the $\left[\begin{array}{ll}0 & 1\end{array}\right]$ interval. ${ }^{16}$

\footnotetext{
${ }^{16}$ For more on methodology, see Appendix 2.
} 
Table 2 provides the descriptive statistics for the endogenous variables and the explanatory variables for the three strata separately. The results of econometric estimation are given in Tables 3, 4 and 5. In addition to the results of OLS (Table 3) and GLM with logit link (Table 4) we report the Blinder-Oaxaca Decomposition (Table 5). The last approach does not yield perceptible difference compared to the general case. However, it identifies and quantifies factors behind average inter-group discrimination and decomposes it into two parts: those due to different observable characteristics or "endowments" across groups and those due to different effects of characteristics or "coefficients" of groups.

\section{Results and discussion}

Let us now explain the results from the regressions. First, we provide the linear regression results with strata dummies corrected for heteroscedasticity in Table 3. Each column in Table 3 reports the regression results for different types of public goods with and without minority (Muslim) concentration at the village level. Not surprisingly, distance travelled to access public amenities such as transport and health services are positively and significantly affected by proximity to block headquarters and towns. This implies that although we do not find evidence of direct discrimination in provision of public goods against minority clusters, general incapacity or reluctance among public authorities in delivering the basic requirements cannot be ruled out. It seems that awareness, access to information through newspapers etc. and proximity to larger towns, create positive influence on public goods provision. On the flip side therefore, geographic distance and insufficient collective action due to lack of awareness push large sections to direct exclusions.

In fact, villages dominated by agricultural labourers report large distances travelled for accessing railway connections and this is significant at $1 \%$ level. Furthermore, as there are fewer villages in quartile 4, the distance travelled to access public goods goes up 
significantly - explaining extreme marginalization for a considerable section of the population. Note that, we do not find evidence of a negative relationship between lack of public goods and percentage share of minority population at the village level. However, when the minority population is distributed over various strata, there is clear evidence of this negative correlation. For strata 1, i.e. villages with minority population in the top $20 \%$ category, we find that the distance covered for accessing health facilities is longer (see Tables 2 and 3). All of these regression analyses have reasonably high adjusted- $\mathrm{R}^{2}$ values.

Next, the GLM in Table 4 compares results once by including Muslim population as a regressor and then excluding it. When Muslim population at the village level is included, proportion of households not using institutional delivery is positive and significant. It implies that larger the Muslim population lower is the rate of institutional delivery. Similarly, when Muslims are included, distance to nearest township goes up and that can be construed as a factor behind lower childbirth in hospitals. But it seems to be a rather general phenomenon, as the coefficient (0.0032) goes up even when Muslims are excluded. This is indicative of historic development deficits that have not been attended to.

Similarly, high proportion of agricultural labour lowers availability of paved roads, houses with electricity, houses with public provision of drinking water, etc. Once again, inclusion of Muslim population has stronger impact on non-availability of drinking water through public taps. Moreover, participation in local meetings and activities surrounding local self-governance seems to have detrimental effect on availability of paved roads and electricity connections. Since, the data does not allow us to venture further into such relationships, we suggest that there could be a reverse causation in effect, i.e., respondents who face lesser and lesser access to these facilities are involved in such participation at an increasing rate. 
Notwithstanding, inclusion of the bottom quartile dummy for district HDI rank generates expected signs: greater is the number of villages in this quartile, with and without the minority share, availability of paved roads get worse $(-0.182$ and -0.176$)$ and dependence on publicly provided drinking water is higher (0.166 and 0.153$)$. Since inclusion of minority population in the bottom quartile makes both coefficients stronger and statistically significant at $1 \%$ level, there may be a clear case of negligence on the part of the state.

Finally, Table 5 provides the results of Blinder-Oaxaca decomposition for analyzing the underlying causes of differences, if any, in public goods delivery in two different sets of villages based on concentration of minority population. In the absence of any discrimination, on average all the villages would have similar access to publicly provided facilities. The Blinder-Oaxaca Decomposition technique is employed to verify this. The approach identifies and quantifies the causes of average extent of inter-group discrimination and decomposes it into two effects - those due to different observable characteristics or 'endowments' across groups and those due to different effects of characteristics or 'coefficients' of groups. ${ }^{17}$ According to our specification, Group A villages belong to S3 category containing villages within blocks with bottom 30\% minority population. On the other hand, Group B villages belong to blocks with top $20 \%$ (S1) and middle $50 \%$ (S2) minority population. Based on these two categories we estimated the group specific regression models 1 and 2 and then performed the Blinder-Oaxaca three fold decomposition to see whether there is any significant difference in the dependent variable between the two groups. We have also conducted the Oaxaca Decomposition for the Muslim Dummy with Muslim Population $\leq$ $20 \%$, Muslim Population $\leq 30 \%$, Muslim Population $\leq 40 \%$ and Muslim Population $\leq 50 \%$. We only report the Oaxaca Decomposition result for Muslim Population $\leq 30 \%$ [where Muslim Dummy $(M)=1$ for Muslim Population $\leq 30 \%$ and $=0$ otherwise] for distance to

\footnotetext{
${ }^{17}$ For a general description of the methodology, see Appendix 2.
} 
public health facilities, distance to nearest bus stop, distance to railway station and average years of highest education. For others, we get similar results regarding the overall difference between the two groups of villages based on these classifications.

Table 5 reports models 1 and 2 with endowment effects and overall effects for these categories. For example, the endowment effect of distance travelled for accessing public health facilities is negative and significant. It implies that the expected change in group B's mean outcome regarding access to public health is negative. Next, the coefficient effect of distance to railway station (for Muslims in the $\leq 30 \%$ category) is influenced by distance to block head quarter and it is negative (-6.0675) and significant at 5\% level. This implies that the relevant group expects the 'distance to railway station' as explained by 'distance to block head quarter' to go up if they belonged to the top $70 \%$ category of minority concentration. In addition, the overall effect (endowment and coefficient) is also negative and significant at 5\% level.

This immediately suggests that profiling of minority groups in highly concentrated regions leads to lower and lower access to basic public amenities. Not surprisingly, the interaction between newspaper subscription and the highest level of education is positive and significant and weaker for the concentration of Muslims above 30\%. In general, therefore, most of the results obtained from the OLS and GLM models are corroborated in the decomposition exercise along with further evidence suggesting presence of strong horizontal inequality regarding provision of public goods.

In terms of regression analysis reported in Tables 3 and 4 we find that higher concentration of Muslim population does not affect provision of public goods in some cases, indicating an absence of religion specific discrimination. However, in some of the other cases we find that there is a clear indication of discrimination based on religion. In fact, the Blinder-Oaxaca decomposition as reported in Table 5 suggests the presence of religion 
specific discrimination. However, one should be careful in interpreting the results in the context of causality. We cannot test the hypothesis of causality in a strict statistical sense because our data is over a cross section of villages. However, we already argued in Section 3 that on the ground of individual rationality poor provision of public goods can not have a negative impact on the concentration of Muslim population. So any significant relation between provision of public goods and Muslim concentration implies a religion specific discrimination.

\section{Concluding Remarks}

While economic and social discrimination against certain religious and ethnic groups is common in many countries, direct evidence is often hard to come by. We used a large sample survey of the minority concentrated districts in West Bengal to document and formalize evidence on horizontal inequality in terms of access to public goods. The results corroborate the recent Justice Sachar Committee Report focusing exclusively on the socioeconomic conditions of religious minorities in India. We collected primary household level data from 11 districts in rural West Bengal. We used this to investigate if religious minorities face horizontal inequality driven by provision of public good and whether such discrimination is quantifiable.

Thus, we focused on access to various types of public goods. We classified the minority population (Muslims form the largest minority group in West Bengal and almost twice the national average), into three broad strata. We estimated their access to targeted and non-targeted public goods such as drinking water, distance to health facilities, distance and quality of educational facilities, transport facilities, condition of roads, etc. This was based on the level of minority concentration as well as other conventional explanatory factors like 
literacy level, access to information, participation in Panchayats, occupational types, etc. For the standard OLS and GLM models we reported evidence with and without the minority group dummy. In many cases, we observed that distance to block headquarter, literacy rate and the district dummy for the worst quartile rank (according to district-level Human Development Indicator) are significant factors behind poor infrastructure and health facilities that minorities are exposed to.

As an extension, we reported the Blinder-Oaxaca decomposition for four major categories and computed both endowment effects and coefficients effects. At least for 'distance travelled to access health services' and 'transport facilities', we report presence of extreme horizontal inequality in public provisions when minority concentration is rather high. For West Bengal it seems to counter the notion that disadvantaged minority groups can significantly influence supply of public goods through political representation.

Moreover, these outcomes strongly support the main concern of Justice Sachar Committee Report. The paper provides direct evidence on the extent of horizontal inequality in access to public goods across religious communities. These results, although limited to a state in India, may be applicable to a broader context. In fact, continued discrimination or strategic negligence by the state has immense impact on socio-economic exclusion of the people and may cause significant political disturbances. The fact that ethnic strife can result from public policies is a very recent subject of analysis with a multidisciplinary outreach (Kanbur, Rajaram and Varshney, 2011). Some of these tensions have already surfaced in recent times and taken the shape of regional conflicts and moves towards cessation from the country or state. Further evidence on horizontal inequality in public provisions and religious/ethnic tensions should reshape public policies in future. 


\section{References}

Ahmed, I (2005), Politicization of Religion in Post-Secular, Post-Globalization India: Newer Dynamics, Newer Challenges, Asian Scholarship Foundation: Bangkok, Annual Fellows Conference Papers, Fifth Annual Conference Bangkok, July 25-26.

Akerlof, G (1976), The economics of caste and of the rat race and other woeful tales, The Quarterly Journal of Economics, 90, 4, 599-617.

Alesina, A, Baqir, R and Easterly, W (1999), Public goods and ethnic divisions, The Quarterly Journal of Economics, 114, 4, 1243-1284.

Banerjee, A and Somanathan, R (2007), The political economy of public goods: Some evidence from India, Journal of Development Economics, 82, 287-314.

Banerjee, A, Iyer, L and Somanathan, R (2005), History, social divisions, and public goods in rural India, Journal of the European Economic Association, 3, 2-3, 639647.

Bardhan, P, Mookherjee, D and Parra Torrado, M (2010), Impact of political reservations in West Bengal local governments on anti-poverty targeting, Journal of Globalization and Development, 1, 1, Art. 5.

Becker, G (1969), The Economics of Discrimination, Chicago: University of Chicago Press.

Besley, T, Pande, R, Rahman, L and Rao, V (2004), The Politics of Public Goods Provision: Evidence from Indian Local Government, Journal of the European Economic Association, 2, 2-3, 416-426.

Bisin, A, Patacchini, E, Verdier, T and Zenou, Y (2008), Are Muslim immigrants different in terms of cultural integration? Journal of the European Economic Association 6, 2-3, 445-456.

Brasington, D. M (2003), Snobbery, racism or mutual distaste: What promotes and hinders cooperation in local public-good provision? The Review of Economics and Statistics, $85,4,874-883$.

Chin, A and Prakash, N (2010), The redistributive effects of political reservation for minorities: Evidence from India, Journal of Development Economics, In Press, Corrected Proof, Available online 30 October 2010.

Constant, A, Gataullina, L, Zimmermann, K and Zimmermann, L (2006), Clash of Cultures: Muslims and Christians in the Ethnosizing Process, Bonn: IZA Discussion Paper No. 2350.

Crost, B and Kambhampati, U (2010), Political Market Characteristics and the Provision of Educational Infrastructure in North India, World Development, 38, 2, 195-204.

Duflo, E (2005), Why political reservations? Journal of the European Economic Association, 3, 2-3, 668-678. 
Government of India (2006), Social, Economic and Educational Status of the Muslim Community of India: A Report by Justice Rajinder Sachar Committee, New Delhi: Prime Minister's High Level Committee Cabinet Secretariat.

Joanis, M (2010), The Road to power: partisan loyalty and the centralized provision of local infrastructure, Public Choice, 146, 1-2, 117-143.

Kanbur, R, Rajaram, P and Varshney, A (2011), Ethnic Diversity and Ethnic Strife. An Interdisciplinary Perspective, World Development, 39, 2, 147-158.

Kar, S (2011), Mapping the Socially Excluded: Beyond Poverty Measurements: Report on Primary Survey in Cooch Behar, West Bengal, Centre for Studies in Social Sciences, Calcutta, India.

Kijima, Yoko (2006), Caste and Tribe Inequality: Evidence from India, 1983-1999, Economic Development and Cultural Change, 54, 369-404.

Miguel, E and Gugerty, M. K. (2005), Ethnic diversity, social sanctions, and public goods in Kenya, Journal of Public Economics, 89, 11-12, 2325-2368.

Moser, C (2008), Poverty Reduction, Patronage, or Vote Buying? The Allocation of Public Goods and the 2001 Election in Madagascar, Economic Development and Cultural Change, 57, 137-162.

Morris, C T and Adelman, I (1980), The religious factor in economic development, World Development, 8, 7-8, 491-501.

National Sample Survey Organisation (2001): Concepts and Definitions Used in NSS, Golden Jubilee Publication, Government of India.

National Sample Survey Organisation (2010): Note on Sample Design and Estimation Procedure, NSS 66 th. Round, Government of India.

Pande, Rohini (2003), Can mandated political representation increase policy inuence for disadvantaged minorities? Theory and evidence from India, American Economic Review, 93, 4, 1132-1151.

Sengupta, B (2010), Provision of public goods in a federal economy: The role of party politics, European Journal of Political Economy, In Press, Corrected Proof, Available online 7 May 2010.

Sharif, I (2011), Does political competition lessen ethnic discrimination? Evidence from Sri Lanka, Journal of Development Economics, 94, 277-289.

Welch, F (1967), Labor-market discrimination: Extrapolation of income differences in the rural south, Journal of Political Economy, 75, 584- 96.

Zhang, X, Fan, S, Zhang, L and Huang, J (2004), Local governance and public goods provision in rural China, Journal of Public Economics, 88, 12, 2857-2871. 


\section{Appendix 1}

Table 2: Averages and Standard Deviations (within parentheses) across all villages and S1, S2 and S3 classified villages for the dependent and independent variables:

\begin{tabular}{|c|c|c|c|c|c|}
\hline \multicolumn{2}{|r|}{ Variables } & $\begin{array}{l}\text { Across all } \\
\text { Villages }\end{array}$ & S1 & $\mathrm{S} 2$ & S3 \\
\hline \multirow{8}{*}{$\begin{array}{l}0 \\
\tilde{z} \\
0 \\
0 \\
0 \\
0 \\
0 \\
0 \\
0\end{array}$} & $\begin{array}{l}\text { Distance travelled for accessing } \\
\text { Public Health Facilities }(\mathrm{Km})\end{array}$ & $\begin{array}{c}5.65 \\
(4.97)\end{array}$ & $\begin{array}{c}6.63 \\
(4.94)\end{array}$ & $\begin{array}{c}5.33 \\
(4.06)\end{array}$ & $\begin{array}{c}5.47 \\
(6.24)\end{array}$ \\
\hline & Distance of Nearest Bus Stop (Km) & $\begin{array}{l}2.96 \\
(3.70)\end{array}$ & $\begin{array}{c}3.24 \\
(3.45)\end{array}$ & $\begin{array}{c}2.81 \\
(3.76)\end{array}$ & $\begin{array}{l}3.027 \\
(3.82)\end{array}$ \\
\hline & $\begin{array}{l}\text { Distance of the Nearest Railway } \\
\text { Station }(\mathrm{Km})\end{array}$ & $\begin{array}{c}13.80 \\
(15.02)\end{array}$ & $\begin{array}{c}15.97 \\
(18.73)\end{array}$ & $\begin{array}{c}14.24 \\
(14.33)\end{array}$ & $\begin{array}{c}11.41 \\
(12.72)\end{array}$ \\
\hline & $\begin{array}{l}\text { Average Years of Highest } \\
\text { Education }\end{array}$ & $\begin{array}{l}5.15 \\
(1.78)\end{array}$ & $\begin{array}{c}4.71 \\
(1.67)\end{array}$ & $\begin{array}{l}5.18 \\
(1.64)\end{array}$ & $\begin{array}{l}5.43 \\
(2.04)\end{array}$ \\
\hline & $\begin{array}{l}\text { Proportion of Households not } \\
\text { visiting Govt. places for Child Birth }\end{array}$ & $\begin{array}{c}56.45 \\
(31.46) \\
\end{array}$ & $\begin{array}{c}61.08 \\
(31.41) \\
\end{array}$ & $\begin{array}{c}59.50 \\
(30.68) \\
\end{array}$ & $\begin{array}{c}47.86 \\
(31.44) \\
\end{array}$ \\
\hline & Proportion of Paved Roads & $\begin{array}{l}34.95 \\
(24.56)\end{array}$ & $\begin{array}{c}33.91 \\
(24.64)\end{array}$ & $\begin{array}{c}37.40 \\
(24.15)\end{array}$ & $\begin{array}{l}31.53 \\
(25.01)\end{array}$ \\
\hline & $\begin{array}{l}\text { Proportion of Households } \\
\text { Electrified }\end{array}$ & $\begin{array}{c}34.69 \\
(27.56)\end{array}$ & $\begin{array}{c}30.98 \\
(25.94)\end{array}$ & $\begin{array}{c}35.98 \\
(27.28)\end{array}$ & $\begin{array}{l}35.26 \\
(29.74)\end{array}$ \\
\hline & $\begin{array}{l}\text { Proportion of Households using } \\
\text { Public provided Drinking Water }\end{array}$ & $\begin{array}{c}53.70 \\
(31.78)\end{array}$ & $\begin{array}{c}54.23 \\
(34.52)\end{array}$ & $\begin{array}{l}55.13 \\
(31.4)\end{array}$ & $\begin{array}{c}50.91 \\
(30.44)\end{array}$ \\
\hline \multirow{9}{*}{ 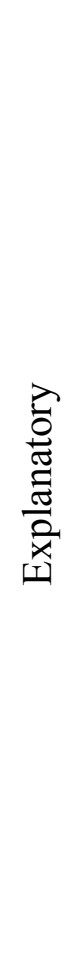 } & $\%$ of Muslim in Village Population & $\begin{array}{l}39.86 \\
(36.13)\end{array}$ & $\begin{array}{c}49.21 \\
(39.86)\end{array}$ & $\begin{array}{c}41.72 \\
(34.58)\end{array}$ & $\begin{array}{c}29.75 \\
(33.67)\end{array}$ \\
\hline & $\begin{array}{l}\text { Average Land Holding } \\
\text { (in bigha }=1 / 3 \text { acre) }\end{array}$ & $\begin{array}{c}0.54 \\
(1.20) \\
\end{array}$ & $\begin{array}{c}0.57 \\
(2.08) \\
\end{array}$ & $\begin{array}{c}0.46 \\
(0.52) \\
\end{array}$ & $\begin{array}{c}0.66 \\
(1.15) \\
\end{array}$ \\
\hline & Block Head Quarter (Km) & $\begin{array}{c}9.44 \\
(6.96)\end{array}$ & $\begin{array}{l}9.65 \\
(6.35)\end{array}$ & $\begin{array}{c}9.83 \\
(6.92)\end{array}$ & $\begin{array}{c}8.64 \\
(7.46)\end{array}$ \\
\hline & Nearest Town (Km) & $\begin{array}{c}18.38 \\
(18.09) \\
\end{array}$ & $\begin{array}{c}16.96 \\
(14.99) \\
\end{array}$ & $\begin{array}{c}20.69 \\
(19.85)\end{array}$ & $\begin{array}{c}15.56 \\
(16.69)\end{array}$ \\
\hline & Newspaper subscription & $\begin{array}{c}15.12 \\
(18.77) \\
\end{array}$ & $\begin{array}{c}13.53 \\
(17.85) \\
\end{array}$ & $\begin{array}{c}14.03 \\
(15.78) \\
\end{array}$ & $\begin{array}{l}18.14 \\
(23.4) \\
\end{array}$ \\
\hline & Decentralization & $\begin{array}{c}22.79 \\
(33.13) \\
\end{array}$ & $\begin{array}{c}20.14 \\
(31.77) \\
\end{array}$ & $\begin{array}{c}24.12 \\
(33.76) \\
\end{array}$ & $\begin{array}{c}22.52 \\
(33.28) \\
\end{array}$ \\
\hline & Literacy Rate (Male) & $\begin{array}{r}70.90 \\
(16.84) \\
\end{array}$ & $\begin{array}{c}67.01 \\
(18.25) \\
\end{array}$ & $\begin{array}{c}71.63 \\
(15.21) \\
\end{array}$ & $\begin{array}{c}72.54 \\
(18.06) \\
\end{array}$ \\
\hline & Agricultural Labour (Male) & $\begin{array}{l}21.05 \\
(15.62)\end{array}$ & $\begin{array}{c}19.87 \\
(14.24)\end{array}$ & $\begin{array}{c}22.35 \\
(15.90)\end{array}$ & $\begin{array}{c}19.74 \\
(16.08)\end{array}$ \\
\hline & Average Annual Expenditure & $\begin{array}{l}34195.23 \\
(20624.81)\end{array}$ & $\begin{array}{l}31677.18 \\
(18161.84)\end{array}$ & $\begin{array}{l}35212.01 \\
(21860.65)\end{array}$ & $\begin{array}{c}34350.51 \\
(20239.60)\end{array}$ \\
\hline
\end{tabular}

Source: Own Household and Village Survey Data. 
Table 3: Linear Regression Results with Robust HC3 Standard Errors

\begin{tabular}{|c|c|c|c|c|c|c|c|c|}
\hline Regressor & $\begin{array}{l}\text { Distance } \\
\text { travelled for } \\
\text { accessing } \\
\text { Public } \\
\text { Health } \\
\text { Facilities } \\
(\mathrm{Km})\end{array}$ & $\begin{array}{l}\text { Distance } \\
\text { travelled for } \\
\text { accessing } \\
\text { Public } \\
\text { Health } \\
\text { Facilities } \\
\text { (Km) }\end{array}$ & $\begin{array}{c}\text { Distance of } \\
\text { Nearest Bus } \\
\text { Stop }(\mathrm{Km})\end{array}$ & $\begin{array}{c}\text { Distance of } \\
\text { Nearest Bus } \\
\text { Stop }(\mathrm{Km})\end{array}$ & $\begin{array}{c}\text { Distance of } \\
\text { the Nearest } \\
\text { Railway } \\
\text { Station } \\
(\mathrm{Km})\end{array}$ & $\begin{array}{c}\text { Distance of } \\
\text { the Nearest } \\
\text { Railway } \\
\text { Station } \\
(\mathrm{Km})\end{array}$ & $\begin{array}{c}\text { Average } \\
\text { Years of } \\
\text { Highest } \\
\text { Education }\end{array}$ & $\begin{array}{c}\text { Average } \\
\text { Years of } \\
\text { Highest } \\
\text { Education }\end{array}$ \\
\hline $\begin{array}{l}\% \text { of Muslim in } \\
\text { Village } \\
\text { Population }\end{array}$ & $\begin{array}{l}-0.0005 \\
(0.0082)\end{array}$ & - & $\begin{array}{c}0.0083 \\
(0.0065)\end{array}$ & - & $\begin{array}{c}0.0209 \\
(0.0233)\end{array}$ & - & $\begin{array}{c}-0.0108^{*} \\
(0.0027)\end{array}$ & - \\
\hline $\begin{array}{l}\text { Average Land } \\
\text { Holding } \\
\text { (in bigha }=1 / 3 \\
\text { acre) }\end{array}$ & - & - & $\begin{array}{l}-0.0717 \\
(0.2227)\end{array}$ & $\begin{array}{l}-0.0680 \\
(0.2383)\end{array}$ & $\begin{array}{c}1.1466 \\
(1.9889)\end{array}$ & $\begin{array}{c}1.0963 \\
(1.8175)\end{array}$ & $\begin{array}{c}0.0496 \\
(0.0655)\end{array}$ & $\begin{array}{c}0.0441 \\
(0.0913)\end{array}$ \\
\hline $\begin{array}{l}\text { Block Head } \\
\text { Quarter }(\mathrm{Km})\end{array}$ & $\begin{array}{l}0.1916^{*} \\
(0.0662)\end{array}$ & $\begin{array}{l}0.1881^{*} \\
(0.0665)\end{array}$ & $\begin{array}{l}0.1805^{*} \\
(0.0493)\end{array}$ & $\begin{array}{l}0.1774^{*} \\
(0.0491)\end{array}$ & $\begin{array}{l}0.3431 \# \\
(0.1732)\end{array}$ & $\begin{array}{l}0.3384 \# \\
(0.1720)\end{array}$ & $\begin{array}{l}-0.0081 \\
(0.0128)\end{array}$ & $\begin{array}{l}-0.0040 \\
(0.0134)\end{array}$ \\
\hline $\begin{array}{l}\text { Nearest Town } \\
(\mathrm{Km})\end{array}$ & $\begin{array}{l}0.0659 \# \\
(0.0296)\end{array}$ & $\begin{array}{l}0.0672 \# \\
(0.0279)\end{array}$ & $\begin{array}{c}0.0174 \\
(0.0164)\end{array}$ & $\begin{array}{c}0.0207 \\
(0.0160)\end{array}$ & $\begin{array}{l}0.2033^{*} \\
(0.0670)\end{array}$ & $\begin{array}{l}0.2159^{*} \\
(0.0639)\end{array}$ & $\begin{array}{l}0.0137 \# \\
(0.0054)\end{array}$ & $\begin{array}{c}0.0091 \\
(0.0054)\end{array}$ \\
\hline $\begin{array}{l}\text { Households } \\
\text { Reading } \\
\text { Newspaper (\%) }\end{array}$ & $\begin{array}{l}-0.0202 \\
(0.0145)\end{array}$ & $\begin{array}{c}-0.0192 \\
(0.0142)\end{array}$ & $\begin{array}{l}-0.0353 * \\
(0.0082)\end{array}$ & $\begin{array}{l}-0.0374 * \\
(0.0085)\end{array}$ & $\begin{array}{l}-0.0741 \# \\
(0.0353)\end{array}$ & $\begin{array}{l}-0.0753 \# \\
(0.0345)\end{array}$ & $\begin{array}{l}0.0488^{*} \\
(0.0067)\end{array}$ & $\begin{array}{l}0.0515^{*} \\
(0.0071)\end{array}$ \\
\hline Decentralization & $\begin{array}{l}-0.0137 \\
(0.0080)\end{array}$ & $\begin{array}{l}-0.0131 \\
(0.0078)\end{array}$ & $\begin{array}{l}-0.0034 \\
(0.0062)\end{array}$ & $\begin{array}{l}-0.0026 \\
(0.0063)\end{array}$ & $\begin{array}{l}-0.0205 \\
(0.0213)\end{array}$ & $\begin{array}{l}-0.0167 \\
(0.0206)\end{array}$ & $\begin{array}{c}0.0010 \\
(0.0029)\end{array}$ & $\begin{array}{l}-0.0001 \\
(0.0030)\end{array}$ \\
\hline $\begin{array}{l}\text { Agricultural } \\
\text { Labour (Male) }\end{array}$ & $\begin{array}{l}-0.0190 \\
(0.0195)\end{array}$ & $\begin{array}{l}-0.0179 \\
(0.0194)\end{array}$ & - & - & $\begin{array}{l}0.1672^{*} \\
(0.0556)\end{array}$ & $\begin{array}{l}0.1698^{*} \\
(0.0550)\end{array}$ & $\begin{array}{l}-0.0174 * \\
(0.0058)\end{array}$ & $\begin{array}{l}-0.0168 * \\
(0.0059)\end{array}$ \\
\hline $\begin{array}{l}\text { Bottom quartile } \\
\text { Dummy for } \\
\text { district HDI rank }\end{array}$ & $\begin{array}{l}-1.2006 \# \\
(0.5889)\end{array}$ & $\begin{array}{l}-1.2221 \# \\
(0.6228)\end{array}$ & $\begin{array}{l}-0.8002 \\
(0.4578)\end{array}$ & $\begin{array}{l}-0.7579 \\
(0.4450)\end{array}$ & $\begin{array}{l}-1.9500 \\
(1.6485)\end{array}$ & $\begin{array}{l}-1.6406 \\
(1.5681)\end{array}$ & $\begin{array}{c}0.0883 \\
(0.2149)\end{array}$ & $\begin{array}{c}0.0354 \\
(0.2166)\end{array}$ \\
\hline S1 Dummy & - & $\begin{array}{l}1.2184 \# \\
(0.6171)\end{array}$ & - & $\begin{array}{c}0.2668 \\
(0.4603)\end{array}$ & - & $\begin{array}{c}3.0342 \\
(2.1795)\end{array}$ & - & $\begin{array}{l}-0.4804 \# \\
(0.1985)\end{array}$ \\
\hline Constant & $\begin{array}{l}3.9783^{*} \\
(0.7801)\end{array}$ & $\begin{array}{l}3.6577^{*} \\
(0.7696)\end{array}$ & $\begin{array}{l}1.4747 \# \\
(0.5735)\end{array}$ & $\begin{array}{l}1.7241^{*} \\
(0.5181)\end{array}$ & $\begin{array}{l}4.0295 \# \\
(2.0313)\end{array}$ & $\begin{array}{c}3.8353 \\
(2.0116)\end{array}$ & $\begin{array}{l}4.9808^{*} \\
(0.2522)\end{array}$ & $\begin{array}{l}4.6784 * \\
(0.2275)\end{array}$ \\
\hline $\mathrm{R}^{2}$ & 0.1863 & 0.1964 & 0.1955 & 0.1911 & 0.2012 & 0.2060 & 0.3889 & 0.3622 \\
\hline Adjusted $\mathrm{R}^{2}$ & 0.1647 & 0.1751 & 0.1747 & 0.1702 & 0.1779 & 0.1829 & 0.3712 & 0.3437 \\
\hline
\end{tabular}

Note: $\#$ and * indicate significant at $5 \%$ and $1 \%$ levels of significance.

Source: Survey data. 
Table 4: Marginal Effects using Generalized Linear Models

\begin{tabular}{|c|c|c|c|c|c|c|c|c|}
\hline Regressor Regresnd & $\begin{array}{l}\text { Proportion } \\
\text { of } \\
\text { Household } \\
\text { s not } \\
\text { visiting } \\
\text { Govt. } \\
\text { places for } \\
\text { Child } \\
\text { Birth } \\
\end{array}$ & $\begin{array}{c}\text { Proportion } \\
\text { of } \\
\text { Household } \\
\text { s not } \\
\text { visiting } \\
\text { Govt. } \\
\text { places for } \\
\text { Child } \\
\text { Birth } \\
\end{array}$ & $\begin{array}{l}\text { Proportion } \\
\text { of Paved } \\
\text { Roads }\end{array}$ & $\begin{array}{l}\text { Proportion } \\
\text { of Paved } \\
\text { Roads }\end{array}$ & $\begin{array}{l}\text { Proportion } \\
\text { of } \\
\text { Household } \\
\mathrm{s} \\
\text { Electrified }\end{array}$ & $\begin{array}{c}\text { Proportion } \\
\text { of } \\
\text { Household } \\
\mathrm{s} \\
\text { Electrified }\end{array}$ & $\begin{array}{c}\text { Proportion } \\
\text { of } \\
\text { Household } \\
\text { s using } \\
\text { Public } \\
\text { provided } \\
\text { Drinking } \\
\text { Water }\end{array}$ & $\begin{array}{c}\begin{array}{c}\text { Proportion } \\
\text { of }\end{array} \\
\text { Household } \\
\text { s using } \\
\text { Public } \\
\text { provided } \\
\text { Drinking } \\
\text { Water }\end{array}$ \\
\hline Muslim Population & $\begin{array}{l}0.0021 * \\
(0.0005)\end{array}$ & - & $\begin{array}{c}0.0005 \\
(0.0004)\end{array}$ & - & $\begin{array}{c}0.0002 \\
(0.0004)\end{array}$ & - & $\begin{array}{l}-0.0009 \\
(0.0005)\end{array}$ & - \\
\hline $\begin{array}{c}\text { Average Land } \\
\text { Holding } \\
\text { (in bigha }=1 / 3 \text { acre) }\end{array}$ & $\begin{array}{l}-0.0355^{*} \\
(0.0124)\end{array}$ & $\begin{array}{l}-0.0376^{*} \\
(0.0124)\end{array}$ & $\begin{array}{l}-0.0083 \\
(0.0141)\end{array}$ & $\begin{array}{l}-0.0091 \\
(0.0135)\end{array}$ & $\begin{array}{c}0.0041 \\
(0.0140)\end{array}$ & $\begin{array}{c}0.0035 \\
(0.0153)\end{array}$ & $\begin{array}{l}-0.0089 \\
(0.0155)\end{array}$ & $\begin{array}{l}-0.0074 \\
(0.0152)\end{array}$ \\
\hline $\begin{array}{l}\text { Block Head Quarter } \\
(\mathrm{Km})\end{array}$ & $\begin{array}{l}-0.0020 \\
(0.0027)\end{array}$ & $\begin{array}{l}-0.0020 \\
(0.0027)\end{array}$ & $\begin{array}{l}-0.0040 \\
(0.0022)\end{array}$ & $\begin{array}{l}-0.0040 \\
(0.0023)\end{array}$ & $\begin{array}{l}-0.0036 \\
(0.0021)\end{array}$ & $\begin{array}{l}-0.0037 \\
(0.0021)\end{array}$ & $\begin{array}{l}-0.0043 \\
(0.0028)\end{array}$ & $\begin{array}{l}-0.0044 \\
(0.0029)\end{array}$ \\
\hline Nearest Town $(\mathrm{Km})$ & $\begin{array}{l}0.0022 \# \\
(0.0010)\end{array}$ & $\begin{array}{l}0.0032^{*} \\
(0.0010)\end{array}$ & $\begin{array}{l}-0.00001 \\
(0.0008)\end{array}$ & $\begin{array}{c}0.0002 \\
(0.0008)\end{array}$ & $\begin{array}{l}-0.0013 \\
(0.0011)\end{array}$ & $\begin{array}{l}-0.0013 \\
(0.0011)\end{array}$ & $\begin{array}{l}-0.0003 \\
(0.0012)\end{array}$ & $\begin{array}{l}-0.0007 \\
(0.0012)\end{array}$ \\
\hline News Paper & $\begin{array}{l}-0.0030 * \\
(0.0010)\end{array}$ & $\begin{array}{l}-0.0030^{*} \\
(0.0011)\end{array}$ & - & - & $\begin{array}{l}0.0055^{*} \\
(0.0009)\end{array}$ & $\begin{array}{l}0.0055^{*} \\
(0.0009)\end{array}$ & $\begin{array}{l}-0.0006 \\
(0.0009)\end{array}$ & $\begin{array}{l}-0.0005 \\
(0.0009)\end{array}$ \\
\hline Decentralization & - & - & $\begin{array}{l}-0.0002 \\
(0.0004)\end{array}$ & $\begin{array}{l}-0.0001 \\
(0.0004)\end{array}$ & $\begin{array}{l}-0.0011 * \\
(0.0004)\end{array}$ & $\begin{array}{l}-0.0011^{*} \\
(0.0004)\end{array}$ & $\begin{array}{l}0.0011 \# \\
(0.0006)\end{array}$ & $\begin{array}{c}0.0010 \\
(0.0006)\end{array}$ \\
\hline Literacy Rate & $\begin{array}{l}-0.0042 * \\
(0.0015)\end{array}$ & $\begin{array}{l}-0.0051^{*} \\
(0.0015)\end{array}$ & $\begin{array}{l}0.0023 * \\
(0.0009)\end{array}$ & $\begin{array}{l}0.0020 \# \\
(0.0009)\end{array}$ & $\begin{array}{l}0.0065^{*} \\
(0.0011)\end{array}$ & $\begin{array}{l}0.0063^{*} \\
(0.0010)\end{array}$ & - & - \\
\hline $\begin{array}{l}\text { Agricultural Labour } \\
\text { (Male) }\end{array}$ & - & - & $\begin{array}{l}-0.0027^{*} \\
(0.0009)\end{array}$ & $\begin{array}{l}-0.0027^{*} \\
(0.0009)\end{array}$ & $\begin{array}{l}-0.0036^{*} \\
(0.0010)\end{array}$ & $\begin{array}{l}-0.0036^{*} \\
(0.0010)\end{array}$ & $\begin{array}{l}-0.0025 \# \\
(0.0012)\end{array}$ & $\begin{array}{r}-0.0024 \# \\
(0.0012)\end{array}$ \\
\hline$\%$ of Paved Roads & $\begin{array}{l}-0.1665 \# \\
(0.0739)\end{array}$ & $\begin{array}{l}-0.1461 \# \\
(0.0730)\end{array}$ & - & - & - & - & - & - \\
\hline $\begin{array}{l}\text { Bottom quartile } \\
\text { Dummy for district } \\
\text { HDI rank }\end{array}$ & $\begin{array}{l}-0.0335 \\
(0.0414)\end{array}$ & $\begin{array}{c}0.0039 \\
(0.0401)\end{array}$ & $\begin{array}{l}-0.1819^{*} \\
(0.0308)\end{array}$ & $\begin{array}{l}-0.1761^{*} \\
(0.0305)\end{array}$ & $\begin{array}{c}0.0082 \\
(0.0303)\end{array}$ & $\begin{array}{c}0.0110 \\
(0.0295)\end{array}$ & $\begin{array}{l}0.1665^{*} \\
(0.0417)\end{array}$ & $\begin{array}{l}0.1528 * \\
(0.0405)\end{array}$ \\
\hline S1 Dummy & - & $\begin{array}{c}0.0524 \\
(0.0415)\end{array}$ & - & $\begin{array}{c}0.0022 \\
(0.0321)\end{array}$ & - & $\begin{array}{c}-0.0314 \\
(0.0301)\end{array}$ & - & $\begin{array}{c}0.0035 \\
(0.0446)\end{array}$ \\
\hline $\begin{array}{l}\text { Avg Exp (Bottom } \\
20 \% \text { Villages) } \\
\text { Dummy }\end{array}$ & $\begin{array}{l}-0.0590 \\
(0.0507)\end{array}$ & $\begin{array}{c}-0.0694 \\
(0.0504)\end{array}$ & $\begin{array}{c}-0.0973 * \\
(0.0309)\end{array}$ & $\begin{array}{c}-0.0982^{*} \\
(0.0314)\end{array}$ & $\begin{array}{c}0.0602 \\
(0.0429)\end{array}$ & $\begin{array}{c}0.0633 \\
(0.0429)\end{array}$ & $\begin{array}{c}0.0199 \\
(0.0456)\end{array}$ & $\begin{array}{c}0.0201 \\
(0.0454)\end{array}$ \\
\hline Deviance & 130.6074 & 135.4457 & 80.3949 & 80.7123 & 76.7427 & 76.5884 & 145.1103 & 146.1182 \\
\hline Pearson & 111.7259 & 115.1816 & 72.5962 & 72.9353 & 68.3885 & 68.3501 & 120.8442 & 121.5778 \\
\hline
\end{tabular}

Note: $\#$ and * indicate significant at $5 \%$ and $1 \%$ levels of significance.

Source: Survey data. 
Table 5: Blinder-Oaxaca Decomposition with Robust HC3 Standard Errors

\begin{tabular}{|c|c|c|c|c|c|c|c|c|c|}
\hline $\begin{array}{c}\text { Regressand } \\
\downarrow\end{array}$ & Regressor $\rightarrow$ & $\begin{array}{l}\text { Average } \\
\text { Land } \\
\text { Holding } \\
\text { (in bigha } \\
=1 / 3 \\
\text { acre) }\end{array}$ & $\begin{array}{l}\text { Block } \\
\text { Head } \\
\text { Quarter } \\
(\mathrm{Km})\end{array}$ & $\begin{array}{l}\text { Nearest } \\
\text { Town } \\
(\mathrm{Km})\end{array}$ & $\begin{array}{l}\text { News } \\
\text { Paper }\end{array}$ & $\begin{array}{l}\text { Literacy } \\
\text { Rate } \\
\text { (Male) }\end{array}$ & $\begin{array}{c}\text { Agricultur } \\
\text { al Labour } \\
\text { (Male) }\end{array}$ & $\begin{array}{l}\text { Quartile } 4 \\
\text { Dummy }\end{array}$ & $\mathrm{R}^{2}$ \\
\hline \multirow{3}{*}{$\begin{array}{l}\text { Distance } \\
\text { traveled for } \\
\text { accessing } \\
\text { Public } \\
\text { Health } \\
\text { Facilities } \\
\text { (Km) }\end{array}$} & $\begin{array}{c}\text { Model } 1(\mathrm{~A}) \\
(\mathrm{S} 3 \text { Dummy=1) }\end{array}$ & - & - & - & - & - & - & $\begin{array}{l}-2.0153 \# \\
(0.9466)\end{array}$ & 0.3705 \\
\hline & $\begin{array}{c}\text { Model } 2(B) \\
(\text { S3 Dummy=0) }\end{array}$ & - & $\begin{array}{l}0.1440 * \\
(0.0476)\end{array}$ & $\begin{array}{l}0.0403 \# \\
(0.0186)\end{array}$ & $\begin{array}{l}-0.0360 \# \\
(0.0173)\end{array}$ & - & - & - & 0.1257 \\
\hline & Endowments & - & - & - & - & - & - & - & - \\
\hline \multirow{2}{*}{$\begin{array}{c}\text { Distance of } \\
\text { Bus Stop } \\
(\mathrm{Km})\end{array}$} & $\begin{array}{c}\text { Model } 1(\mathrm{~A}) \\
(\mathrm{S} 3 \text { Dummy=1) }\end{array}$ & - & - & - & - & - & - & $\begin{array}{l}-2.2811 \# \\
(1.0679)\end{array}$ & 0.3343 \\
\hline & $\begin{array}{c}\text { Model } 2(B) \\
(\text { S3 Dummy }=0)\end{array}$ & - & $\begin{array}{l}0.1889^{*} \\
(0.0573)\end{array}$ & & $\begin{array}{l}-0.0256 \# \\
(0.0114)\end{array}$ & $\begin{array}{l}-0.0435 \# \\
(0.0193)\end{array}$ & - & - & 0.2167 \\
\hline \multirow{4}{*}{$\begin{array}{l}\text { Distance of } \\
\text { Railway } \\
\text { Station } \\
\text { (Km) }\end{array}$} & $\begin{array}{c}\text { Model } 1(\mathrm{~A}) \\
(\mathrm{M} \text { Dummy }=1 \text { if } \\
\text { Muslim } \\
\text { Population } \leq 30 \% \text { ) }\end{array}$ & - & - & $\begin{array}{l}0.3382 * \\
(0.1054)\end{array}$ & - & - & $\begin{array}{l}0.2401 \# \\
(0.0976)\end{array}$ & - & 0.2527 \\
\hline & $\begin{array}{c}\text { Model } 2(\mathrm{~B}) \\
\text { (M Dummy=0 } \\
\text { otherwise) }\end{array}$ & - & - & - & - & - & & & 0.2005 \\
\hline & Endowments & - & - & $\begin{array}{l}-1.3264 \# \\
(0.6082)\end{array}$ & - & - & & & \\
\hline & Coefficients & - & $\begin{array}{l}-6.0675 \# \\
(2.7290)\end{array}$ & - & - & - & - & - & - \\
\hline \multirow{3}{*}{$\begin{array}{l}\text { Average } \\
\text { Years of } \\
\text { Highest } \\
\text { Education }\end{array}$} & $\begin{array}{c}\text { Model } 1(\mathrm{~A}) \\
(\mathrm{M} \text { Dummy }=1 \text { if } \\
\text { Muslim } \\
\text { Population } \leq 30 \%)\end{array}$ & - & - & - & $\begin{array}{l}0.0575^{*} \\
(0.0098)\end{array}$ & - & $\begin{array}{l}-0.0307 \# \\
(0.0136)\end{array}$ & - & 0.60 \\
\hline & $\begin{array}{c}\text { Model } 2(\mathrm{~B}) \\
\text { (M Dummy }=0 \\
\text { otherwise) }\end{array}$ & $\begin{array}{l}0.0819 \# \\
(0.0339)\end{array}$ & - & - & $\begin{array}{l}0.0414^{*} \\
(0.0092)\end{array}$ & - & - & - & 0.232 \\
\hline & Coefficients & - & - & - & - & - & - & - & - \\
\hline
\end{tabular}

Note: $\#$ and * indicate significant at $5 \%$ and $1 \%$ levels of significance.

Source: Survey data. 


\section{Appendix 2}

Table 6. Changing Population Share of Religious Minorities in West Bengal

\begin{tabular}{|c|c|c|c|}
\hline $\begin{array}{ll}\text { State/District } & \text { Years } \\
\end{array}$ & 1981 & 1991 & 2001 \\
\hline West Bengal & 21.51 & 23.61 & 25.25 \\
\hline Bardhaman & 17.6 & 19.55 & 19.78 \\
\hline Birbhum & 30.98 & 33.06 & 35.08 \\
\hline Coochbehar & 20.78 & 23.34 & 24.24 \\
\hline Dakshin Dinajpur & 35.79 & 23.51 & 24.02 \\
\hline Haora & 20.17 & 22.22 & 24.44 \\
\hline Malda & 45.27 & 47.49 & 49.72 \\
\hline Murshidabad & 58.67 & 61.4 & 63.67 \\
\hline Nadia & 24.08 & 24.92 & 25.41 \\
\hline North 24 Parganas & 22.5 & 24.17 & 24.22 \\
\hline South 24 Parganas & 26.82 & 29.94 & 33.24 \\
\hline Uttar Dinajpur & 35.79 & 45.35 & 47.36 \\
\hline
\end{tabular}

\section{GLM}

It is well known that GLMs are flexible enough to allow regression-based modelling for normal as well as non-normal data. To illustrate, suppose that a variable $y, 0 \leq y \leq 1$, is to be explained by a set of $K$ explanatory variables $x \equiv\left(x_{1}, x_{2}, \ldots, x_{K}\right)$, with the convention that $x_{1} \equiv 1$. In the usual multiple regression model it is assumed that $y$ has a normal and independent distribution with mean $\mu$ and standard deviation $\sigma$ and takes the form $E(y \mid x)=\mu=x \beta$, where $\beta$ is a vector of regression coefficients. However, this linear model does not ensure that the predicted values of $y$ lie within the meaningful interval $(0,1)$. In case of transforming the data and using the equation $E\left[\ln \left(\frac{y}{1-y}\right) \mid x\right]=x \beta$, for estimating $y$ one loses data for the extreme values, 0 and 1. In that case, the proportion $\left(\frac{y}{1-y}\right)$ cannot be computed. To overcome these problems GLM introduce a one-to-one continuous differentiable transformation $G(),. E\left(y_{i} \mid x_{i}\right)=G\left(x_{i} \beta\right)$, where $G($.$) is called the link$ 
function and satisfies $0<G(z)<1$ for all $z \in \mathfrak{R}$. For the proportions data $G($.) is chosen to be the cumulative logistic distribution function $G(z) \equiv \Lambda(z) \equiv \exp (z) /[1+\exp (z)]$. Further, heteroscedasticity would be present since $\operatorname{Var}(y \mid x)$ is unlikely to be constant when $0 \leq y \leq 1$. For this reason, computation of GLM follows under the assumption that

$$
\operatorname{Var}\left(y_{i} \mid x_{i}\right)=\sigma^{2} G\left(x_{i} \beta\right)\left[1-G\left(x_{i} \beta\right)\right] \quad \text { for some } \quad \sigma^{2}>0
$$

where, $G()=.\Lambda($.$) . The maximum likelihood estimation procedure is applied to estimate y_{i}$ with robust standard errors.

\section{Blinder-Oaxaca Decomposition}

A general description of the methodology used under the Blinder-Oaxaca Decomposition is given below.

Suppose there are two groups A and B with outcome variable $\mathrm{Y}$ and a set of predictors (X).

We consider a basic linear relationship between these variables given by

$Y_{l}=X_{l}^{\prime} \beta_{l}+\varepsilon_{l}, E\left(\varepsilon_{l}\right)=0, l \in\{A, B\}$

where $\mathrm{X}$ is the matrix of explanatory variables including a constant, $\beta$ is the vector of slope parameters and intercept term and $\varepsilon$ is the error. Then the mean outcome difference between the groups is given by

$$
\begin{aligned}
R & =E\left(Y_{A}\right)-E\left(Y_{B}\right) \\
& =E\left(X_{A}^{\prime}\right) \beta_{A}-E\left(X_{B}^{\prime}\right) \beta_{B}
\end{aligned}
$$

This difference can be rearranged into a "three fold decomposition":

$$
\begin{aligned}
& \begin{array}{l}
R=E+C+I \\
\text { where } E
\end{array}=\left[E\left(X_{A}\right)-E\left(X_{B}\right)\right]^{\prime} \beta_{B} \\
& \qquad C=E\left(X_{B}^{\prime}\right)\left(\beta_{A}-\beta_{B}\right) \\
& \text { and } I=\left[E\left(X_{A}\right)-E\left(X_{B}\right)\right]^{\prime}\left(\beta_{A}-\beta_{B}\right)
\end{aligned}
$$

The component $E$ is the "endowments effect" and it determines the expected change in group B's mean outcome if it had group A's predictor levels. The next component $C$ is the 
contribution of "differences in coefficients" and measures the expected change in group B's mean outcome if it had group A's coefficients. This is often used as a measure of discrimination. And $I$ is the interaction term which accounts for the fact that differences in endowments and coefficients exist simultaneously between the two groups. 